\title{
Stannyl Complexes of Rhodium and Iridium: Preparation of Mono- and Bis(trihydridestannyl) Derivatives
}

\author{
Gabriele Albertin, ${ }^{*[a]}$ Stefano Antoniutti, ${ }^{[a]}$ Daniela Baldan, ${ }^{[a]}$ and Jesús Castro ${ }^{[b]}$
}

Mono- and bis(trichlorostannyl) complexes $\left[\mathrm{MCl}\left(\mathrm{SnCl}_{3}\right)\left(\eta^{5}\right.\right.$ $\left.\left.\mathrm{C}_{5} \mathrm{Me}_{5}\right)\left\{\mathrm{P}(\mathrm{OR})_{3}\right\}\right](\mathbf{1}, 2)$ and $\left[\mathrm{M}\left(\mathrm{SnCl}_{3}\right)_{2}\left(\eta^{5}-\mathrm{C}_{5} \mathrm{Me}_{5}\right)\left\{\mathrm{P}(\mathrm{OR})_{3}\right\}\right](3,4)$ $(\mathrm{M}=\mathrm{Rh}, \mathrm{Ir} ; \mathrm{R}=\mathrm{Me}$, Et) were prepared by allowing chloro compounds $\mathrm{MCl}_{2}\left(\eta^{5}-\mathrm{C}_{5} \mathrm{Me}_{5}\right)\left[\mathrm{P}(\mathrm{OR})_{3}\right]$ to react with anhydrous $\mathrm{SnCl}_{2}$ in refluxing 1,2-dichloroethane. Treatment of trichlorostannyl complexes of iridium 2 and 4 with $\mathrm{NaBH}_{4}$ in ethanol afforded hydride-trihydridestannyl derivatives $\left[\mathrm{IrH}\left(\mathrm{SnH}_{3}\right)\left(\eta^{5}\right.\right.$ $\left.\left.\mathrm{C}_{5} \mathrm{Me}_{5}\right)\left\{\mathrm{P}(\mathrm{OR})_{3}\right\}\right] \quad(5)$ and bis(trihydridestannyl) $\left[\operatorname{Ir}\left(\mathrm{SnH}_{3}\right)_{2}\left(\eta^{5}\right.\right.$ -

\section{Introduction}

The chemistry of inorganic and organometallic complexes containing metal-main group metal bonds has shown a resurgence of interest in recent years. ${ }^{[1-5]}$ In particular, complexes containing stannyl groups of the type $\mathrm{SnX}_{3}, \mathrm{SnR}_{3}$ and $\mathrm{SnH}_{3}$ as ligands, which display novel reactivity, played a prominent role in such renaissance.

We have a long-standing interest in the chemistry of stannyl complexes of transition metals ${ }^{[5,6]}$ and have reported the synthesis and reactivity of trihydride $\mathrm{M}-\left[\mathrm{SnH}_{3}\right]$ and triorganostannyl $\mathrm{M}-\left[\mathrm{SnR}_{3}\right]$ derivatives of both the $\mathrm{Mn}$ and $\mathrm{Fe}$ triads. The interesting properties shown, in particular, by the trihydridestannyl ligand $\mathrm{SnH}_{3}{ }^{[5]}$ prompted us to extend our study to the Rh and Ir central metals ${ }^{[7]}$ to test whether tin trihydride compounds can be prepared and how the reactivity of the stannyl groups is influenced by the metal fragments. The results of these studies, which include the preparation of the first tin trihydride complexes of iridium, are reported here.

\section{Results and Discussion}

Preparation of stannyl complexes. Dichloro complexes $\left[\mathrm{MCl}_{2}\left(\eta^{5}-\mathrm{C}_{5} \mathrm{Me}_{5}\right)\left\{\mathrm{P}(\mathrm{OR})_{3}\right\}\right]$ react with equimolar amounts of $\mathrm{SnCl}_{2}$ to give the trichlorostannyl derivatives $\left[\mathrm{MCl}\left(\mathrm{SnCl}_{3}\right)\left(\eta^{5}-\mathrm{C}_{5} \mathrm{Me}_{5}\right)\{\mathrm{P}\right.$ $\left.\left.(\mathrm{OR})_{3}\right\}\right](1,2)$ in good yields. In the presence of an excess of $\mathrm{SnCl}_{2}$, instead, the reaction affords bis(trichlorostannyl) derivatives $\left[\mathrm{M}\left(\mathrm{SnCl}_{3}\right)_{2}\left(\eta^{5}-\mathrm{C}_{5} \mathrm{Me}_{5}\right)\left\{\mathrm{P}(\mathrm{OR})_{3}\right\}\right](3,4)$, as shown in Scheme 1.

\section{[a] Prof. G. Albertin, Prof. S. Antoniutti, D. Baldan}

Dipartimento di Scienze Molecolari e Nanosistemi, Università $\mathrm{Ca}^{\prime}$ Foscari Venezia, Via Torino 155, 30172 Mestre Venezia, Italy

E-mail: albertin@unive.it

[b] Prof. J. Castro

Departamento de Química Inorgánica, Universidade de Vigo, Facultade de Química, Edificio de Ciencias Experimentais, 36310 Vigo (Galicia), Spain

Supporting information for this article is available on the WWW under https://doi.org/10.1002/slct.201803373
$\left.\left.\mathrm{C}_{5} \mathrm{Me}_{5}\right)\left\{\mathrm{P}(\mathrm{OR})_{3}\right\}\right](6)$, the reaction of which with methylpropiolate $\mathrm{HC} \equiv \mathrm{CCOOMe}$ led to trivinylstannyl derivatives [IrH $\{\mathrm{Sn}[\mathrm{C}$ $\left.\left.\left.(\mathrm{COOMe})=\mathrm{CH}_{2}\right]_{3}\right\}\left(\eta^{5}-\mathrm{C}_{5} \mathrm{Me}_{5}\right)\left\{\mathrm{P}(\mathrm{OMe})_{3}\right\}\right] \quad(7 \mathrm{a})$ and $[\mathrm{Ir}\{\mathrm{Sn}[\mathrm{CH}=\mathrm{C}(\mathrm{H})$ $\left.\left.\mathrm{COOMe}]_{3}\right\}_{2}\left(\eta^{5}-\mathrm{C}_{5} \mathrm{Me}_{5}\right)\left\{\mathrm{P}(\mathrm{OMe})_{3}\right\}\right](8 \mathrm{a})$. The complexes were characterised spectroscopically (IR and ${ }^{1} \mathrm{H},{ }^{31} \mathrm{P},{ }^{13} \mathrm{C},{ }^{119} \mathrm{Sn} N M R$ ) and by $\mathrm{X}$-ray crystal structure determination of $\left[\operatorname{Ir}\left(\mathrm{SnCl}_{3}\right)_{2}\left(\eta^{5}-\mathrm{C}_{5} \mathrm{Me}_{5}\right)\right.$ $\left.\left\{\mathrm{P}(\mathrm{OMe})_{3}\right\}\right](4 \mathrm{a})$.

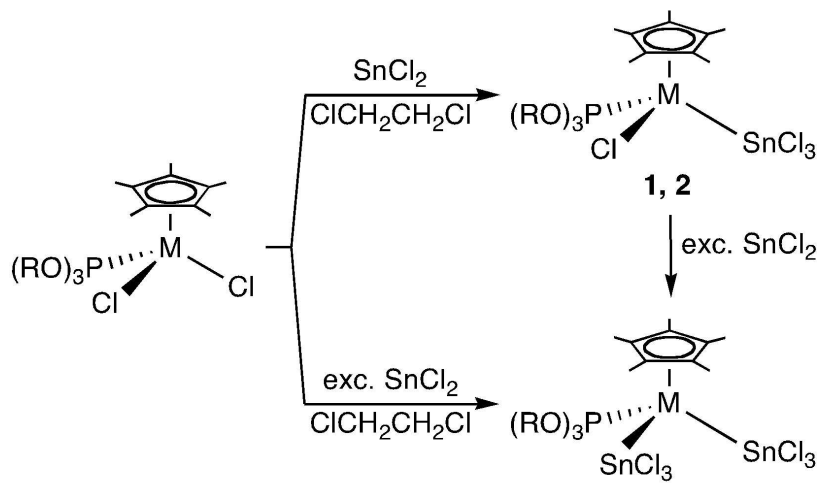

3, 4

Scheme 1. Preparation of complexes 1-4. $M=R h(1,3), \operatorname{Ir}(2,4) ; R=M e(a)$, Et (b).

Indeed, treatment of monostannyl complexes 1 and $\mathbf{2}$ with an excess of $\mathrm{SnCl}_{2}$ in refluxing 1,2-dichloroethane afforded the bis(stannyl) derivatives 3 and $\mathbf{4}$.

The reaction proceeds with the insertion of $\mathrm{SnCl}_{2}$ into the $\mathrm{M}-\mathrm{Cl}$ bond to give monostannyl complexes 1 and 2 , which can undergo a second insertion affording the bis(trichlorostannyl) derivatives $\mathbf{3}$ and $\mathbf{4}$ as final products. Both the first and second insertion have slow rate and need refluxing conditions in 1,2dichloroethane to afford pure samples of compounds 1-4 in a reasonable time. It is worth also noting that the use of $\mathrm{SnCl}_{2} \bullet \mathrm{H}_{2} \mathrm{O}$ in ethanol instead of $\mathrm{SnCl}_{2}$ in the reaction of $\left[\mathrm{MCl}_{2}\left(\eta^{5}-\mathrm{C}_{5} \mathrm{Me}_{5}\right)\left\{\mathrm{P}(\mathrm{OR})_{3}\right\}\right]$ did not afford trichlorostannyl complexes like 1-4 but intractable mixtures of compounds. Only the use of anhydrous $\mathrm{SnCl}_{2}$ in 1,2-dichloroethane allows to prepare mono- and bis(trichlorostannyl) complexes of rhodium and iridium stabilised by our pentamethylcyclopentadienyl half-sandwich fragments.

The reactivity of chlorostannyl complexes 1-4 with $\mathrm{NaBH}_{4}$ was studied and the results are shown in Scheme 2. While both 


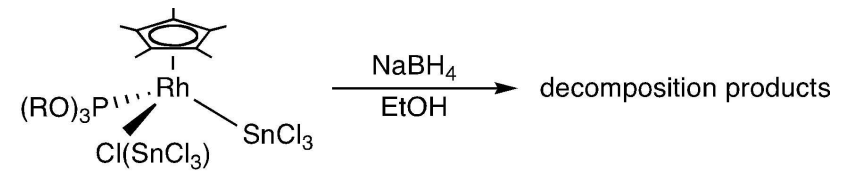

1,3

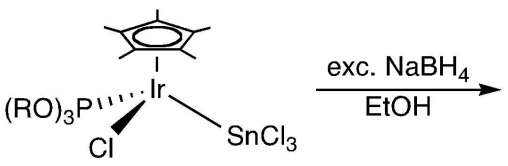

2

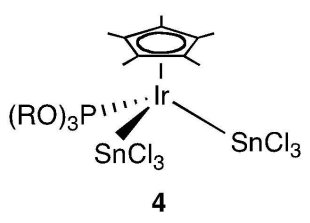<smiles>CC(C)OCc1ccccc1</smiles>

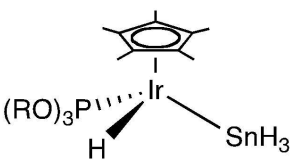

5

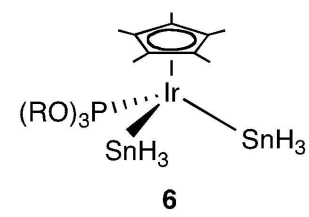

Scheme 2. Preparation of complexes 5 and 6. $\mathrm{R}=\mathrm{Me}(\mathbf{a})$, Et (b).

the mono- and bis(trichlorostannyl) complexes of rhodium 1 and 3 react with $\mathrm{NaBH}_{4}$ affording, in all conditions, decomposition products, the iridium derivatives 2 and 4 quickly react with $\mathrm{NaBH}_{4}$ in ethanol affording trihydridestannyl derivatives $\left[\mathrm{IrH}\left(\mathrm{SnH}_{3}\right)\left(\eta^{5}-\mathrm{C}_{5} \mathrm{Me}_{5}\right)\left\{\mathrm{P}(\mathrm{OR})_{3}\right\}\right](5)$ and $\left[\mathrm{Ir}\left(\mathrm{SnH}_{3}\right)_{2}\left(\eta^{5}-\mathrm{C}_{5} \mathrm{Me}_{5}\right)\left\{\mathrm{P}(\mathrm{OR})_{3}\right\}\right]$ (6), respectively, which were isolated as yellow-orange solids and characterised. The reaction proceeds in any case with the substitution of all chloro groups, bonded either to Sn or to Ir, affording hydride-trihydridestannyl $\mathbf{5}$ and bis(trihydridestannyl) 6 derivatives in good yields.

The use of $\mathrm{NaBH}_{4}$ as a reagent to prepare tin trihydride complexes turns out to be an interesting synthetic method in tin chemistry that we had previously used to synthesise several $[\mathrm{M}]-\mathrm{SnH}_{3}$ derivatives. ${ }^{[5, \mathrm{~b}, \mathrm{~b}, \mathrm{c}, \mathrm{e}, \mathrm{c}, \mathrm{d}, \mathrm{f}]}$ In the present study, this route allowed the preparation of the first iridium complexes containing tin trihydride as a ligand. As observed with other stannyl derivatives, ${ }^{[a, b, b d, f]}$ the nature of the central metal and the ancillary ligands seem to be crucial for stabilising tin trihydride complexes. The pentamethylcyclopentadienyl half-sandwich fragment with phosphite ligand is able to stabilise both monoand bis(tin trihydride) derivatives, but only with iridium. In the case of rhodium, only trichlorostannyl complexes were prepared, resulting the related trihydride species very unstable and not isolable. In addition, it is worth noting that metal complexes containing two tin trihydride groups are very rare and only two examples of $\mathrm{Ru}$ and Os, reported by $\mathrm{us}^{\left[{ }^{[6]}\right]}$ were known until now. The use of the $\left[\operatorname{Ir}\left(\eta^{5}-\mathrm{C}_{5} \mathrm{Me}_{5}\right)\left\{\mathrm{P}(\mathrm{OR})_{3}\right\}\right]$ fragment afforded a new example of this class of compounds.

Good analytical data were obtained for all the stannyl complexes 1-6, which were isolated as yellow or orange solids stable in air and in solution of common organic solvents, where they behave as non-electrolytes. ${ }^{[8]}$ Infrared and NMR data $\left({ }^{1} \mathrm{H}\right.$, ${ }^{31} \mathrm{P},{ }^{119} \mathrm{Sn}$ ) support the proposed formulation, which was further

confirmed by X-ray crystal structure determination of [Ir $\left.\left(\mathrm{SnCl}_{3}\right)_{2}\left(\eta^{5}-\mathrm{C}_{5} \mathrm{Me}_{5}\right)\left\{\mathrm{P}(\mathrm{OMe})_{3}\right\}\right] \quad(4 \mathrm{a})$, the ORTEP ${ }^{[9]}$ of which is shown in Figure 1.

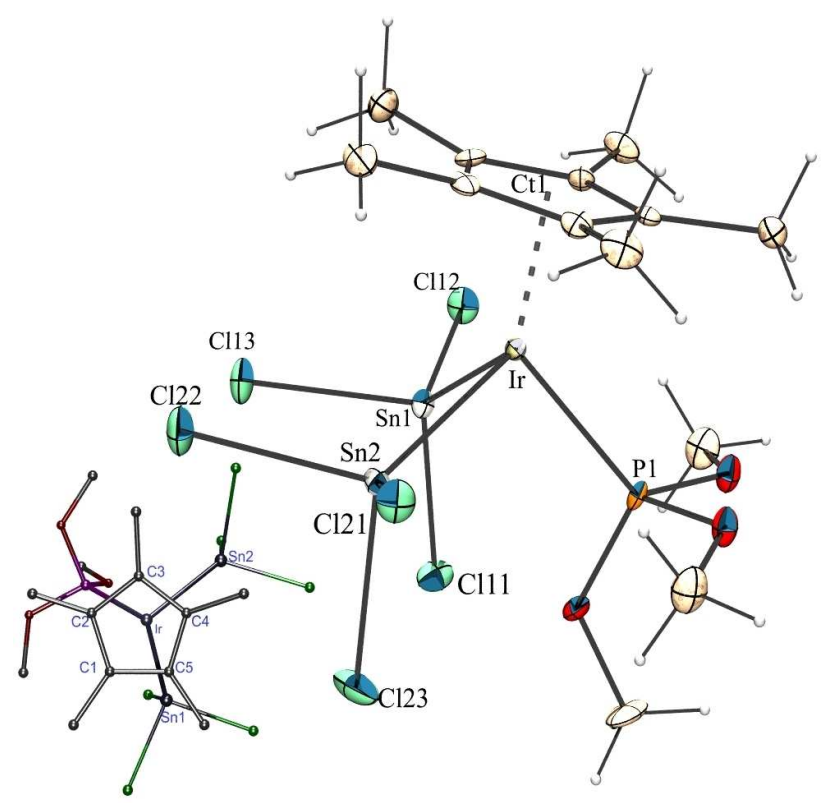

Figure 1. ORTEP scheme of the molecular structure of $4 \mathrm{a}$. The small inset on the left represents the compound drawn perpendicular to the $\mathrm{Ir}-\mathrm{Ct}$ vector.

The structure of complex 4 a contains an iridium atom $\eta^{5}$ coordinated to a pentamethylcyclopentadienyl ligand ( $\mathrm{Cp} *$ ) [ring-slippage $0.039 \AA$ ] and to three monodentate ligands, leading to the formation of a "three-legged piano stool" structure. These ligands are one $\mathrm{P}(\mathrm{OMe})_{3}$ phosphite ligand and two monodentate trichlorostannyl ligands. The geometry of the complex is pseudo-octahedral with the $\mathrm{Cp}^{*}$ ligand occupying three coordination positions and is marked by near- $90^{\circ}$ values for the angles among the legs (Table 1 ) between $90.780(15)$ and $92.74(3)^{\circ}$. The remaining angles between the $\mathrm{Cp}^{*}$ centroid and the donor atoms (expected $125.3^{\circ}$ ) are between $121.92(12)$ and $126.32(8)^{\circ}$, bigger than the CT-Ir-P one as occurs in a related $\mathrm{Rh}$ compound with triphenylphosphine $\left[\mathrm{Cp}{ }^{*} \mathrm{Rh}\left(\mathrm{PPh}_{3}\right)\left(\mathrm{SnCl}_{3}\right)_{2}\right]^{[10]}$

The centroid of $C p^{*}$ ligand is situated at 1.875(2) $\AA$ from the iridium atom, and the average $\mathrm{Ir}-\mathrm{C}$ bond distances for the $\mathrm{Cp}^{*}$ ligand is $2.238 \AA$, being both values similar to those found in the literature, as for example in the cations $\left[\mathrm{Cp}^{*} \mid r C l\left(\mathrm{NH}_{2} \mathrm{NH}_{2}\right)\{\mathrm{P}\right.$ $\left.\left.(\mathrm{OEt})_{3}\right\}\right]^{+}$and $\left[\mathrm{Cp}^{*} \mid \mathrm{rCl}\left(\mathrm{CH}_{3} \mathrm{NHNH}_{2}\right)\left\{\mathrm{P}(\mathrm{OEt})_{3}\right\}\right]^{+},{ }^{[11 \mathrm{a}]}$ or in $\left[\mathrm{Cp} * \mid r\left\{\eta^{1-}\right.\right.$ $\left.\left.\left.\mathrm{C}_{6} \mathrm{H}_{5}(\mathrm{H}) \mathrm{C}=\mathrm{N}-\mathrm{N}=\mathrm{C}(\mathrm{H})\left(\mathrm{C}_{6} \mathrm{H}_{5}\right)\right\} \quad \mathrm{P}(\mathrm{OMe})_{3}\right\}\right]^{+}{ }^{[11 \mathrm{~b}]}$ or also in $\left[\operatorname{lr}\left(\eta^{5}-\right.\right.$ $\left.\left.\mathrm{C}_{5} \mathrm{Me}_{5}\right)\left(\mathrm{N} \equiv \mathrm{CNEt}_{2}\right)_{2}\left\{\mathrm{P}(\mathrm{OMe})_{3}\right\}\right]^{2+}$. $^{[11 \mathrm{c}]}$ However, it is noteworthy the wide range of the Ir-C bonds, from 2.213(5) to 2.263(5) $\AA$, longest values, $\operatorname{Ir}-C(4)$ and $\operatorname{Ir}-C(5)$, quasi-trans to the phosphite ligand, as can be seen in the small inset in Figure 1. The Ir-P [2.2558(12) $\AA$ ] bond length is also similar to those in the abovementioned cation complexes. ${ }^{[1]}$

The two Ir-Sn distances, 2.5709(4) and 2.5734(5) $\AA$, are only slightly longer than those found in the $\left[\mathrm{Cp} * \mathrm{Ir}\left(\mathrm{SnCl}_{3}\right)_{3}\right]^{-}$anion, 


\begin{tabular}{|c|c|c|c|}
\hline $\mathrm{Ir}-\mathrm{CT} 1$ & $1.875(2)$ & $\operatorname{lr}-\mathrm{P}(1)$ & $2.2558(12)$ \\
\hline $\operatorname{Ir}-\mathrm{Sn}(1)$ & $2.5709(4)$ & $\operatorname{Ir}-\operatorname{Sn}(2)$ & $2.5734(5)$ \\
\hline $\mathrm{Ir}-\mathrm{C}(1)$ & $2.227(5)$ & $\operatorname{lr}-C(4)$ & $2.258(5)$ \\
\hline $\operatorname{Ir}-\mathrm{C}(2)$ & $2.228(4)$ & $\operatorname{Ir}-\mathrm{C}(5)$ & $2.263(5)$ \\
\hline $\mathrm{Ir}-\mathrm{C}(3)$ & $2.213(5)$ & $\mathrm{Ir}-\mathrm{C}_{a v}$ & 2.238 \\
\hline $\mathrm{Sn}(1)-\mathrm{Cl}(11)$ & $2.3595(13)$ & $\mathrm{Sn}(2)-\mathrm{Cl}(21)$ & $2.3735(13)$ \\
\hline $\mathrm{Sn}(1)-\mathrm{Cl}(12)$ & $2.3718(13)$ & $\mathrm{Sn}(2)-\mathrm{Cl}(22)$ & $2.3608(13)$ \\
\hline CT1-Ir-P(1) & $126.32(8)$ & CT1-Ir-Sn(1) & $123.92(15)$ \\
\hline $\mathrm{CT} 1-\mathrm{Ir}-\mathrm{Sn}(2)$ & $121.92(12)$ & $\operatorname{Sn}(1)-\operatorname{Ir}-\mathrm{Sn}(2)$ & $90.780(15)$ \\
\hline$P(1)-\operatorname{Ir}-S n(1)$ & $91.45(3)$ & $P(1)-I r-S n(2)$ & $92.74(3)$ \\
\hline $\mathrm{Cl}(13)-\mathrm{Sn}(1)-\mathrm{Cl}(11)$ & $98.31(5)$ & $\mathrm{Cl}(23)-\mathrm{Sn}(2)-\mathrm{Cl}(22)$ & $97.71(5)$ \\
\hline $\mathrm{Cl}(13)-\mathrm{Sn}(1)-\mathrm{Cl}(12)$ & $96.22(5)$ & $\mathrm{Cl}(23)-\mathrm{Sn}(2)-\mathrm{Cl}(21)$ & $98.38(5)$ \\
\hline $\mathrm{Cl}(11)-\mathrm{Sn}(1)-\mathrm{Cl}(12)$ & $96.73(5)$ & $\mathrm{Cl}(22)-\mathrm{Sn}(2)-\mathrm{Cl}(21)$ & $94.39(5)$ \\
\hline $\mathrm{Cl}(13)-\mathrm{Sn}(1)-\mathrm{Ir}$ & $117.73(3)$ & $\mathrm{Cl}(21)-\mathrm{Sn}(2)-\mathrm{Ir}$ & $117.85(3)$ \\
\hline $\mathrm{Cl}(12)-\mathrm{Sn}(1)-\mathrm{Ir}$ & $118.78(4)$ & $\mathrm{Cl}(22)-\mathrm{Sn}(2)-\mathrm{Ir}$ & $120.43(4)$ \\
\hline $\mathrm{Cl}(11)-\mathrm{Sn}(1)-\mathrm{Ir}$ & $123.55(3)$ & $\mathrm{Cl}(23)-\mathrm{Sn}(2)-\mathrm{Ir}$ & $122.33(4)$ \\
\hline
\end{tabular}

between 2.5582(7) $\AA$ and 2.5592(5) $\AA^{[12]}$ The Sn-Ir-Sn angle, $90.780(15)^{\circ}$, is the acutest among donors in the legs. The $\mathrm{Sn}-\mathrm{Cl}$ distances are between $2.3540(14)$ and 2.3735(13) $\AA$. This range is slightly narrower than that found in the $\left[\mathrm{Cp} * \mathrm{Ir}\left(\mathrm{SnCl}_{3}\right)_{3}\right]^{-}$anion or in $\left[\mathrm{Cp}^{*} \mid r\left\{\left(\mathrm{SnCl}_{2}\left(\mathrm{H}_{2} \mathrm{O}\right)_{2}\right\}\left(\mathrm{SnCl}_{3}\right)_{2}\right]\right.$. An interesting feature is that in both $\mathrm{SnCl}_{3}$ ligands one of the $\mathrm{Sn}-\mathrm{Cl}$ distances is slightly longer than the other two, a structural parameter previously observed $^{[11,13]}$ and apparently an usual behaviour for this kind of ligand.

The $\mathrm{Ir}-\mathrm{Sn}-\mathrm{Cl}$ angles between 117.73(3) and $123.55(3)^{\circ}$ and $\mathrm{Cl}-\mathrm{Sn}-\mathrm{Cl}$ angles around $96.9^{\circ}$ (average) show high distortion around tin atoms, far from a tetrahedral disposition usual for trichlorostannyl ligands. ${ }^{[11-14]}$

The ${ }^{1} \mathrm{HNMR}$ spectra of mono- and bis(trichlorostannyl) complexes of rhodium 1 and 3 show the characteristic signals of the ancillary ligands $\mathrm{C}_{5} \mathrm{Me}_{5}$ and $\mathrm{P}(\mathrm{OR})_{3}$ whereas the ${ }^{31} \mathrm{P}$ ones appear as doublets due to the presence of the ${ }^{103} \mathrm{Rh}$ nuclei $\left(J_{31 \mathrm{P} 103 \mathrm{Rh}}=220-208 \mathrm{~Hz}\right)$, with their characteristic satellites due to coupling with the ${ }^{117} \mathrm{Sn}$ and ${ }^{119} \mathrm{Sn}$ nuclei of the $\mathrm{SnCl}_{3}$ groups. However, the presence of this stannyl ligand is confirmed by the ${ }^{119} \mathrm{Sn}$ NMR spectra, which show a multiplet centred at -75.32 to $-76.54 \mathrm{ppm}$ for 1 and at $1-5 \mathrm{ppm}$ for 3 , which can be simulated using an $A M X$ model $\left(A={ }^{31} \mathrm{P}, \mathrm{X}={ }^{103} \mathrm{Rh}\right.$ ) with the parameters reported in the Experimental section (see S.I.). The good fit between the calculated and experimental spectra supports the proposed formulation for the rhodium derivatives.

The ${ }^{31}$ P NMR spectra of the trichlorostannyl derivatives of iridium 2 and 4 show a sharp singlet with the characteristic satellites due to coupling with the ${ }^{117} \mathrm{Sn}$ and ${ }^{119} \mathrm{Sn}$ nuclei of the $\mathrm{SnCl}_{3}$ ligand. The ${ }^{119} \mathrm{Sn}$ NMR spectra confirm its presence showing a doublet at -347.0 to $-342.0 \mathrm{ppm}$ for monostannyl 2 and at -312.6 to -320.4 ppm for bis(stannyl) 4 derivatives, due to coupling with the ${ }^{31} \mathrm{P}$ nuclei, in agreement with the proposed formulation.

The IR spectra of the hydride-trihydridestannyl complexes $\left[\mathrm{IrH}\left(\mathrm{SnH}_{3}\right)\left(\eta^{5}-\mathrm{C}_{5} \mathrm{Me}_{5}\right)\left\{\mathrm{P}(\mathrm{OR})_{3}\right\}\right]$ (5) show one medium-intensity band at $2113-2134 \mathrm{~cm}^{-1}$ attributed to the $v_{1 \mathrm{r}-\mathrm{H}}$ of the hydride and another one, of strong intensity and rather broad, at 1771-
$1755 \mathrm{~cm}^{-1}$ attributed to the stretching of the $\mathrm{Sn}-\mathrm{H}$ bond of the $\mathrm{SnH}_{3}$ ligand. However, two $v_{\mathrm{Sn}-\mathrm{H}}$ bands are expected for the metal-bonded $\mathrm{SnH}_{3}$ group, as had been observed in related Os and Re complexes. ${ }^{[5 a, b]}$ Probably, the difference of the stretching values of the two bands is too small to allow resolution by our instrument and therefore the spectra display only a single enlarged absorption.

Besides the signals of the ancillary ligands, the ${ }^{1} \mathrm{HNMR}$ spectra of 5 show a doublet near $-17 \mathrm{ppm}$ due to the hydride and a slightly broad singlet at 2.93-2.94 ppm, with the characteristic satellites (see S.I., Fig. S1) due to coupling with the ${ }^{117} \mathrm{Sn}$ and ${ }^{119} \mathrm{Sn}$ nuclei and attributed to the $\mathrm{SnH}_{3}$ ligand. The proton-coupled ${ }^{119} \mathrm{Sn}$ NMR spectra of $\mathbf{5}$ appear as quartets of multiplets at -491 to $-489 \mathrm{ppm}$ due to coupling not only with the hydride hydrogen atoms $\mathrm{IrH}$ and $\mathrm{SnH}_{3}$ and with the ${ }^{31} \mathrm{P}$ nuclei, but also with the methyl hydrogen atoms of the $\mathrm{C}_{5} \mathrm{Me}_{5}$ ligand. These multiplets were simulated using an $\mathrm{AMX}_{3} \mathrm{Y}_{15} \mathrm{Z}$ model $\left(\mathrm{A}={ }^{31} \mathrm{P}, \mathrm{M}={ }^{119} \mathrm{Sn}, \mathrm{X}, \mathrm{Z}={ }^{1} \mathrm{H}\right.$ hydride, $\mathrm{Y}={ }^{1} \mathrm{H}$ $\mathrm{C}_{5} \mathrm{Me}_{5}$ ) with the parameters reported in the Experimental section (see S.I., Fig. S2) and the good fit between the experimental and calculated spectra strongly supports the proposed formulation for the hydride-trihydridestannyl derivatives 5.

The IR spectra of the bis(tin trihydride) complexes [Ir $\left.\left(\mathrm{SnH}_{3}\right)_{2}\left(\eta^{5}-\mathrm{C}_{5} \mathrm{Me}_{5}\right)\left\{\mathrm{P}(\mathrm{OR})_{3}\right\}\right]$ (6) show two strong bands at 1733$1765(6 a)$ and at $1767-1798 \mathrm{~cm}^{-1}(6 \mathrm{~b})$ attributed to the $v_{\mathrm{SnH}}$ of the $\mathrm{SnH}_{3}$ group. However, diagnostic for the presence of the $\mathrm{SnH}_{3}$ ligand are both the ${ }^{1} \mathrm{H}$ and ${ }^{119} \mathrm{Sn}$ NMR spectra. A slightly broad singlet, with the characteristic satellites due to coupling with the ${ }^{117} \mathrm{Sn}$ and ${ }^{119} \mathrm{Sn}$ nuclei, was observed in the proton spectra between 3.05 and $3.10 \mathrm{ppm}$ and attributed to the $\mathrm{SnH}_{3}$ group. In addition, the proton-coupled ${ }^{119} \mathrm{Sn}$ NMR spectra of 6 a and $6 \mathrm{~b}$ appear as quartets of doublets of multiplets due to coupling with the hydride, the phosphorus nuclei of the phosphite and the fifteen hydrogens of the pentamethylcyclopentadienyl ligand. These spectra can be simulated with an $\mathrm{AMX}_{6} \mathrm{Y}_{15}$ model $\left(\mathrm{A}={ }^{31} \mathrm{P}, \mathrm{M}={ }^{119} \mathrm{Sn}, \mathrm{X}, \mathrm{Y}={ }^{1} \mathrm{H}\right)$ with the parameters reported in the Experimental section (see S.I.) and 
the good fit between the experimental and calculated spectra strongly support the proposed formulation for the complexes.

Reactions with alkynes. Methylpropiolate $\mathrm{HC} \equiv \mathrm{CCOOMe}$ reacts with both the trihydridestannyl complexes $\left[\mathrm{IrH}\left(\mathrm{SnH}_{3}\right)\left(\eta^{5}\right.\right.$ $\left.\left.\mathrm{C}_{5} \mathrm{Me}_{5}\right)\left\{\mathrm{P}(\mathrm{OMe})_{3}\right\}\right](5 \mathrm{a})$ and $\left[\operatorname{Ir}\left(\mathrm{SnH}_{3}\right)_{2}\left(\eta^{5}-\mathrm{C}_{5} \mathrm{Me}_{5}\right)\left\{\mathrm{P}(\mathrm{OMe})_{3}\right\}\right](6 \mathrm{a})$ to give the trivinylstannyl derivatives $\left[\mathrm{IrH}\left\{\mathrm{Sn}\left[\mathrm{C}(\mathrm{COOMe})=\mathrm{CH}_{2}\right]_{3}\right\}\right.$ $\left.\left(\eta^{5}-\mathrm{C}_{5} \mathrm{Me}_{5}\right) \quad\left\{\mathrm{P}(\mathrm{OMe})_{3}\right\}\right] \quad(7 \mathrm{a})$ and $\left[\operatorname{Ir}\left\{\mathrm{Sn}[\mathrm{CH}=\mathrm{C}(\mathrm{H}) \mathrm{COOMe}]_{3}\right\}_{2}\left(\eta^{5}-\right.\right.$ $\left.\left.\mathrm{C}_{5} \mathrm{Me}_{5}\right)\left\{\mathrm{P}(\mathrm{OMe})_{3}\right\}\right](8 \mathrm{a})$, which were isolated as yellow oils and characterised (Scheme 3).
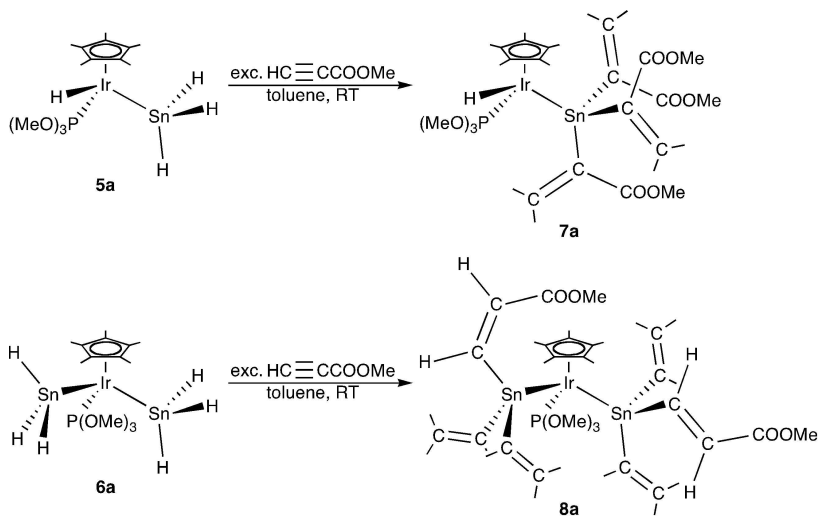

Scheme 3. Preparation of complexes 5 and 6 .

The reaction involves the addition of three $\mathrm{Sn}-\mathrm{H}$ bonds to three alkynes affording the trivinylstannyl derivatives $7 \mathrm{a}$ and $8 \mathrm{a}$. It probably proceeds by sequential addition of $\mathrm{HC} \equiv$ CCOOMe to the $\mathrm{Sn}-\mathrm{H}$ bonds but it is too fast to allow the isolation from $\mathbf{5}$ a of mono- and bis(vinyl) intermediates [Ir]$\mathrm{SnH}_{2}\left\{\mathrm{C}(\mathrm{COOMe})=\mathrm{CH}_{2}\right\} \quad$ and $\quad[\mathrm{Ir}]-\mathrm{SnH}\left\{\mathrm{C}(\mathrm{COOMe})=\mathrm{CH}_{2}\right\}_{2}$. Although only trivinylstannyl complexes are formed with an excess of alkyne, with a ratio $\mathrm{HC} \equiv \mathrm{CCOOMe:[Ir]-SnH} \mathrm{H}_{3}$ or [Ir]$\left(\mathrm{SnH}_{3}\right)_{2}$ lower than 3 or 6 , the products were always mixtures of mono-, di- and trivinyl complexes, which were not separated. Moreover, it is worth noting that no addition of the $\mathrm{Ir}-\mathrm{H}$ bond to alkyne was observed, resulting this hydride ligand always present in the final monotrivinylstannyl complex $7 \mathrm{a}$.

In addition, depending on the nature of the starting complex $5 \mathrm{a}$ and $6 \mathrm{a}$, the addition of the $\mathrm{Sn}-\mathrm{H}$ bond to $\mathrm{HC} \equiv$ CCOOMe affords different vinylstannyl derivatives $7 \mathrm{a}$ and $\mathbf{8 a}$ probably owing to the steric requirements of the bis(trivinylstannyl) derivative $\mathbf{8}$ a.

Phenylacetylene was also reacted with the trihydridestannyl precursors $5 \mathrm{a}$ and $6 \mathrm{a}$ but in this case a mixture of products was obtained, the NMR spectra of which indicate the formation of some vinyl species. However, these species are rather unstable and decomposed in any attempt of separation. It seems therefore that only activated alkynes such as methylpropiolate can undergo addition of the $\mathrm{Sn}-\mathrm{H}$ bond affording stable and isolable trivinylstannyl derivatives.

Although the addition of organotin hydrides $\mathrm{R}_{n} \mathrm{SnH}_{4-n}(n=$ 1-3) to terminal acetylene $\mathrm{RC} \equiv \mathrm{CH}$ is a well-known reaction, ${ }^{[15]}$ the cases of coordinated $\mathrm{SnH}_{3}$ groups to a transition metal are very rare and only two examples are reported in the literature involving $\mathrm{Re}$ and Os derivatives. ${ }^{[5 \mathrm{~d}, 6 \mathrm{~d}]}$ The reaction of our trihydridestannyl derivatives 5 and 6 represents a new example of such a type of reaction, affording the first trivinylstannyl derivatives of iridium.

The complexes $\left[\mathrm{IrH}\left\{\mathrm{Sn}\left[\mathrm{C}(\mathrm{COOMe})=\mathrm{CH}_{2}\right]_{3}\right\}\left(\eta^{5}-\mathrm{C}_{5} \mathrm{Me}_{5}\right)\{\mathrm{P}\right.$ $\left.\left.(\mathrm{OMe})_{3}\right\}\right](7 \mathrm{a})$ and $\left[\mathrm{Ir}\left\{\mathrm{Sn}\left[\mathrm{CH}=\mathrm{C}(\mathrm{H}) \mathrm{COOMe}_{3}\right\}_{2}\left(\eta^{5}-\mathrm{C}_{5} \mathrm{Me}_{5}\right)\left\{\mathrm{P}(\mathrm{OMe})_{3}\right\}\right]\right.$ (8a) were isolated as oils that we were not able to transform into solids. However, their spectroscopic properties (IR and ${ }^{1} \mathrm{H}$, $\left.{ }^{13} \mathrm{C},{ }^{31} \mathrm{P},{ }^{119} \mathrm{Sn} N \mathrm{NMR}\right)$ strongly support the proposed formulations. The IR spectrum of 7 a shows a medium-intensity band at $2111 \mathrm{~cm}^{-1}$ attributed to the $v_{\mathrm{Ir}-\mathrm{H}}$ of the hydride and a strong one at $1700 \mathrm{~cm}^{-1}$ attributed to the $v_{\mathrm{CO}}$ of the ester group of the $\mathrm{C}(\mathrm{COOMe})=\mathrm{CH}_{2}$. The presence of vinylstannyl ligand is confirmed by the ${ }^{1} \mathrm{H},{ }^{13} \mathrm{C}$ and ${ }^{119} \mathrm{Sn}$ NMR spectra. The proton spectrum shows an $A B$ quartet between 7.04 and 6.17 ppm with the characteristic satellites due to coupling with the ${ }^{117} \mathrm{Sn}$ and ${ }^{119} \mathrm{Sn}$ nuclei and attributed to the $\mathrm{H}_{\mathrm{x}}$ and $\mathrm{H}_{\mathrm{y}}$ vinyl protons (Figure 2).

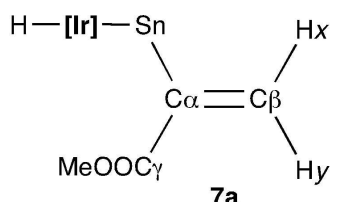

$7 a$

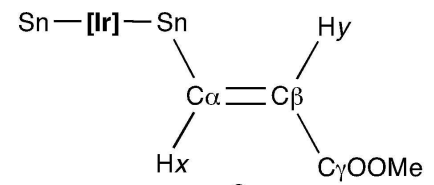

$8 a$
Figure 2. Trivinylstannyl ligand forms in complexes $7 \mathbf{a}$ and $\mathbf{8} \mathbf{a}$.

The ${ }^{2} J_{\mathrm{HH}}$ value of $3.5 \mathrm{~Hz}$ is characteristic of the geminal position of the two vinyl protons. The spectrum also shows a singlet at $3.50 \mathrm{ppm}$ of the methyl group pf the substituent COOMe and a doublet at $-17.55 \mathrm{ppm}$ of the hydride ligand, in agreement with the presence of both the vinyl and hydride groups. Besides the signals of the ancillary ligands $\mathrm{P}(\mathrm{OMe})_{3}$ and $\mathrm{C}_{5} \mathrm{Me}_{5}$, the ${ }^{13} \mathrm{C}$ NMR spectrum shows two signals at 171.62 and $135.98 \mathrm{ppm}$, each with the ${ }^{117} \mathrm{Sn}$ and ${ }^{119} \mathrm{Sn}$ satellites, attributed to the $C \gamma$ and $C \beta$ carbon resonances of the $C \alpha(C \gamma O O M e)=$ $\mathrm{C} \beta \mathrm{H}_{2}$ group. This attribution was confirmed by HMQC and HMBC experiments and by the $J_{13 c 1195 n}$ values, which range from $21 \mathrm{~Hz}$ for $\mathrm{C} \gamma$ to $32 \mathrm{~Hz}$ for $\mathrm{C} \beta$; the resonance for $\mathrm{C} \alpha$ was not unambiguously attributed. The ${ }^{119} \mathrm{Sn}\left\{{ }^{1} \mathrm{H}\right\}$ NMR spectrum of 7 a confirms the presence of the stannyl ligand showing a doublet at $-203.4 \mathrm{ppm}$ due to coupling with the ${ }^{31} \mathrm{P}$ nucleus of the phosphite. The ${ }^{31} \mathrm{PNMR}$ spectrum appears as a singlet at $101.4 \mathrm{ppm}$ with the characteristic satellites, in agreement with the proposed formulation for the complex.

The IR spectrum of the bis(trivinylstannyl) derivative [Ir $\{\mathrm{Sn}$ $\left.\left.[\mathrm{CH}=\mathrm{C}(\mathrm{H}) \mathrm{COOMe}]_{3}\right\}_{2}\left(\eta^{5}-\mathrm{C}_{5} \mathrm{Me}_{5}\right)\left\{\mathrm{P}(\mathrm{OMe})_{3}\right\}\right] \quad(8 \mathrm{a})$ shows a strong band at $1719 \mathrm{~cm}^{-1}$ due to the $v_{\mathrm{CO}}$ of the ester groups $\mathrm{CH}=\mathrm{C}(\mathrm{H})$ COOMe. The ${ }^{1} \mathrm{HNMR}$ spectrum shows an $\mathrm{AB}$ quartet at 7.80 and $6.17 \mathrm{ppm}$, with the ${ }^{117} \mathrm{Sn}$ and ${ }^{119} \mathrm{Sn}$ satellites and attributed to the $\mathrm{H}_{\mathrm{x}}$ and $\mathrm{H}_{\mathrm{y}}$ vinyl protons (Figure 2). The ${ }^{2} J_{\mathrm{HH}}$ value of $19 \mathrm{~Hz}$ suggests a trans position of the two vinyl protons. A singlet at $3.47 \mathrm{ppm}$ due to the methyl group of $\mathrm{CH}=\mathrm{C}(\mathrm{H}) \mathrm{COOMe}$ is also present in the ${ }^{1} \mathrm{HNMR}$ spectrum, matching the presence of the vinyl group. Further support came from the ${ }^{13} \mathrm{CNMR}$ spectrum 
which, besides the signals of the ancillary ligands $\mathrm{P}(\mathrm{OMe})_{3}$ and $\mathrm{C}_{5} \mathrm{Me}_{5}$, shows three signals at $165.39,155.54$ and $135.21 \mathrm{ppm}$, each with the ${ }^{117} \mathrm{Sn}$ and ${ }^{119} \mathrm{Sn}$ satellites, attributed to the $\mathrm{C}_{\gamma}, \mathrm{C} \alpha$ and $C \beta$, respectively, carbon resonances of the $C \alpha(H)=C \beta(H)$ $\mathrm{C} \gamma \mathrm{OOMe}$ group. This attribution was confirmed by HMQC and $\mathrm{HMBC}$ experiments and by the $J_{13 \mathrm{C} 1195 n}$ value ranging from $295 \mathrm{~Hz}$ for $\mathrm{C} \alpha$ to $119 \mathrm{~Hz}$ for $\mathrm{C} \beta$ and $17.5 \mathrm{~Hz}$ for $\mathrm{C} \gamma$.

The ${ }^{119} \mathrm{Sn}\left\{{ }^{1} \mathrm{H}\right\}$ NMR spectrum of $8 \mathrm{a}$ appears as a doublet at $-290.96 \mathrm{ppm}$ due to coupling with the ${ }^{31} \mathrm{P}$ nucleus of the phosphine, whereas the ${ }^{31} \mathrm{P}$ spectrum is a singlet at $79.61 \mathrm{ppm}$ with the characteristic ${ }^{117} \mathrm{Sn}$ and ${ }^{119} \mathrm{Sn}$ satellites, fitting the proposed formulation.

\section{Conclusions}

In this paper we report that the pentamethylcyclopentadienyl fragment $\mathrm{MCl}_{2}\left(\eta^{5}-\mathrm{C}_{5} \mathrm{Me}_{5}\right)\left[\mathrm{P}(\mathrm{OR})_{3}\right]$ stabilises both mono- and bis (trichlorostannyl) derivatives of rhodium and iridium. Reaction with $\mathrm{NaBH}_{4}$ of these compounds allows the synthesis of the first trihydridestannyl derivatives of iridium $\left[\mathrm{IrH}\left(\mathrm{SnH}_{3}\right)\left(\eta^{5}-\mathrm{C}_{5} \mathrm{Me}_{5}\right)\right.$ $\left.\left\{\mathrm{P}(\mathrm{OMe})_{3}\right\}\right]$ and $\left[\operatorname{Ir}\left(\mathrm{SnH}_{3}\right)_{2}\left(\eta^{5}-\mathrm{C}_{5} \mathrm{Me}_{5}\right)\left\{\mathrm{P}(\mathrm{OMe})_{3}\right\}\right]$. Among the properties shown by the $[\mathrm{M}]-\mathrm{SnH}_{3}$ fragments there is the insertion of methylpropiolate into the $\mathrm{Sn}-\mathrm{H}$ bond yielding trivinylstannyl derivatives $[\mathrm{Ir}]-(\mathrm{H})\left\{\mathrm{Sn}\left[\mathrm{C}(\mathrm{COOMe})=\mathrm{CH}_{2}\right]_{3}\right\}$ and $[\mathrm{Ir}]-\{\mathrm{Sn}[\mathrm{CH}=\mathrm{C}(\mathrm{H})$ $\left.\mathrm{COOMe}]_{3}\right\}_{2}$.

\section{Supporting information Summary}

Complete Experimental section including details of crystal data and structure refinement (Table S1); ${ }^{1} \mathrm{H}$ and ${ }^{119} \mathrm{Sn}$ NMR spectra of compound $\mathbf{5} \mathbf{b}$ (Fig. S1, S2, pdf).

\section{Acknowledgements}

The financial support of MIUR (Italy) - PRIN 2016 is gratefully acknowledged.

\section{Conflict of Interest}

The authors declare no conflict of interest.

Keywords: Iridium • Rhodium • Stannyl ligands
Trihydridestannyl - Trivinylstannnyl

[1] a) A. Koppaka, V. Yempally, L. Zhu, G. C. Fortman, M. Temprado, C. D. Hoff, B. Captain, Inorg. Chem. 2016, 55, 307-321; b) Y. H. M. Cabon R. J. M. Klein Gebbink, B. J. Deelman, Dalton Trans. 2011, 40, 8651-8655; c) H. Braunschweig, M. A. Celik, R. D. Dewhurst, M. Heid, F. Hupp, S. S. Sen, Chem. Sci. 2015, 6, 425-435; d) J. Ito, S. Hosokawa, H. B. Khalid, H. Nishiyama, Organometallics 2015, 34, 1377-1383; e) H. Kameo, Y. Baba, S. Sakaki, D. Bourissou, H. Nakazawa, H. Matsuzaka, Organometallics 2017, 36, 2096-2106.

[2] a) R. D. Adams, M. Chen, E. Trufan, Q. Zhang, Organometallics 2011, 30, 661-664; b) E. K. Sharma, A. J. Metta-Magaña, K. H. Pannell, Organometallics 2013, 32, 6218-6225; c) R. D. Adams, M. Chen, G. Elpitiya, Q. Zhang, Organometallics 2012, 31, 7264-7271; d) A. A. Pasynsky, A.I. Blokhin, Yu. V. Torubaev, Zh. V. Dobrokhotova, Russ. J. Coord. Chem. 2011, 37, 879-886; e) B. Therrien, T.-T. Thai, J. Freudenreich, G. SüssFink, S. S. Shapovalov, A. A. Pasynskii, L. Plasseraud, J. Organomet. Chem.
2010, 695, 409-414; f) X. Miao, A. Blokhin, A. Pasynskii, S. Nefedov, S. N. Osipov, T. Roisnel, C. Bruneau, P. H. Dixneuf, Organometallics 2010, 29, 5257-5262; g) P. G. Hayes, C. W. Gribble, R. Waterman, T. D. Tilley, J. Am. Chem. Soc. 2009, 131, 4606-4607; h) S. E. Kabir, A. K. Raha, M. R. Hassan, B. K. Nicholson, E. Rosenberg, A. Sharmin, L. Salassa, Dalton Trans. 2008, 4212-4219; i) L. Carlton, M. A. Fernandes, E. Sitabule, Proc. Natl. Acad. Sci. 2007, 104, 6969-6973.

[3] a) B. Eguillor, M. A. Esteruelas, M. Oliván, E. Oñate, Organometallics 2005, 24, 1428-1438; b) T. Sagawa, K. Ohtsuki, T. Ishiyama, F. Ozawa Organometallics 2005, 24, 1670-1677; c) R. D. Adams, B. Captain, C. B. Hollandsworth, M. Johansson, J. L., Jr. Smith, Organometallics 2006, 25, 3848-3855; d) M. A. Alvarez, M. E. Garcia, A. Ramos, M. A. Ruiz, Organometallics 2006, 25, 5374-5380; e) M. M. Möhlen, C. E. F. Rickard, W. R. Roper, R. G. Whittell, L. J. Wright, Inorg. Chim. Acta 2007, 360, $1287-$ 1297; f) H. Braunschweig, H. Bera, B. Geibel, R. Dörfler, D. Götz, F. Seeler, T. Kupfer, K. Radacki, Eur. J. Inorg. Chem. 2007, 3416-3424; g) C. E. F. Rickard, W. R. Roper, T. J. Woodman, L. J. Wright, Chem. Commun. 1999, 837-838; h) H. Adams, S. G. Broughton, S. J. Walters, M. J. Winter, Chem Commun. 1999, 1231-1232; i) A. M. Clark, C. E. F. Rickard, W. R. Roper, T. J. Woodman, L. J. Wright, Organometallics 2000, 19, 1766-1774; j) S Hermans, B. F. G. Johnson, Chem. Commun. 2000, 1955-1956; k) M. Turki, C. Daniel, S. Záliš, A., Jr. Vlček, J. van Slageren, D. J. Stufkens, J. Am. Chem. Soc. 2001, 123, 11431-11440.

[4] a) S. Hermans, R. Raja, J. M. Thomas, B. F. G. Johnson, G. Sankar, D. Gleeson, Angew. Chem. 2001, 113, 1251-1255; Angew. Chem. Int. Ed. 2001, 40, 1211-1215; b) G.W. Huber, J.W. Shabaker, J. A. Dumesic, Science 2003, 300, 2075; c) J. M. Thomas, B. F. G. Johnson, R. Raja, G. Sankar, P. A. Midgley, Acc. Chem. Res. 2003, 36, 20-30; d) R. D. Adams, B. Captain, M. Johansson, J. L., Jr. Smith, J. Am. Chem. Soc. 2005, 127, 488489; e) R. D. Adams, D. A. Blom, B. Captain, R. Raja, J. M. Thomas, E. Trufan, Langmuir 2008, 24, 9223-9229.

[5] a) G. Albertin, S. Antoniutti, A. Bacchi, M. Bortoluzzi, G. Pelizzi, G. Zanardo, Organometallics 2006, 25, 4235-4237; b) G. Albertin, S. Antoniutti, J. Castro, S. García-Fontán, G. Zanardo, Organometallics 2007 26, 2918-2930; c) G. Albertin, S. Antoniutti, J. Castro, S. García-Fontán, M. Noé, Dalton Trans. 2007, 5441-5452; d) G. Albertin, S. Antoniutti, J. Castro, S. García-Fontán, G. Zanardo, Organometallics 2008, 27, 27892794; e) G. Albertin, S. Antoniutti, A. Bacchi, G. Pelizzi, G. Zanardo, Organometallics 2008, 27, 4407-4418; f) G. Albertin, S. Antoniutti, J. Castro, G. Zanardo, Organometallics 2009, 28, 1270-1273.

[6] a) G. Albertin, S. Antoniutti, S. Paganelli, J. Organomet. Chem. 2009, 694, 3142-3148; b) G. Albertin, S. Antoniutti, J. Castro, G. Zanardo, Inorg. Chim. Acta 2010, 363, 605-616; c) G. Albertin, S. Antoniutti, J. Castro, Organometallics 2010, 29, 3808-3816; d) G. Albertin, S. Antoniutti, J. Castro, Organometallics 2011, 30, 1914-1919; e) G. Albertin, S. Antoniutti, J. Castro, J. Organomet. Chem. 2012, 718, 108-116; f) G. Albertin, S. Antoniutti, J. Castro, S. Da Lio, Organometallics 2013, 32, 3651-3661.

[7] For some reviews on stannyl complexes, see: a) K. M. Mackay, B. K. Nicholson, Comprehensive Organometallic Chemistry, Wilkinson, G.; Stone, F. G. A.; Abel, E. W., Eds.; Pergamon Press: New York, 1982, vol. 2, pp. 1043-1114; b) M. S. Holt, W. L. Wilson, J. H. Nelson, Chem. Rev. 1989, 89, 11-49; c) M. F. Lappert, R. S. Rowe, Coord. Chem. Rev. 1990, 100, 267292; d) A. G. Davies, Comprehensive Organometallic Chemistry, F. G. A. Stone, E. W. Abel, G. Wilkinson, Eds.; Pergamon Press: New York, 1995, vol. 2, pp. 218-297; e) A. G. Davies, Organotin Chemistry, Wiley-VCH: Weinheim, Germany, 2004; f) W. R. Roper, L. J. Wright, Organometallics 2006, 25, 4704-4718.

[8] W. J. Geary, Coord. Chem. Rev. 1971, 7, 81.

[9] a) L. J. Farrugia, J. Appl. Crystallogr. 1997, 30, 565-565; b) POV-Ray v3.7 for Windows, Persistence of Vision Pty. Ltd. (2016) Persistence of Vision Raytracer (Version 3.7)

[10] A. K. Maity, M. Bhattacharjee, S. Roy, J. Organomet. Chem. 2014, 768, 4249.

[11] a) G. Albertin, S. Antoniutti, M. Bortoluzzi, J. Castro, Inorg. Chim. Acta 2018, 470, 139-148; b) G. Albertin, S. Antoniutti, M. Bortoluzzi, J. Castro, F. Sibilla, E. Trave, New J. Chem. 2017, 41, 12976-12988; c) G. Albertin, S. Antoniutti, J. Castro, ChemistrySelect 2018, 3, 11054-11058.

[12] P. A. Abramov, M. N. Sokolov, I. V. Mirzaeva, A. V. Virovets, J. Organomet. Chem. 2014, 754, 32-38.

[13] T. Ghatak, P. Daw, M. Majumdar, J. K. Bera, J. Clust. Sci. 2012, 23, 839851. 
[14] a) P. Daw, T. Ghatak, H. Doucet, J. K. Bera, Organometallics 2013, 32, 4306-4313; b) A. L. Balch, K. M. Waggoner, M. M. Olmstead, Inorg. Chem. 1988, 27, 4511-4513.

[15] a) F. Liron, P. Le Garret, M. Alami, Synlett 1999, 246-248; b) F. Ferri, M. Alami, Tetrahedron 1996, 37, 7971-7974; c) E. Nakamura, D. Machii, T. Inubushi, J. Am. Chem. Soc. 1989, 111, 6849-6850; d) K. Nozaki, K. Oshima, K. Utimoto, J. Am. Chem. Soc. 1987, 109, 2547-2549; e) J. E. Cochran, L. E. Williams, B. S. Bronk, J. A. Calhoun, J. Fassberg, K. G. Clark,
Organometallics 1989, 8, 804-812; f) K. Nozaki, K. Oshima, K. Utimoto, Tetrahedron 1989, 45, 923-933; g) E. J. Corey, R. H. Wollenberg, J. Am. Chem. Soc. 1974, 96, 5581-5583; h) G. Axelrad, D. F. Halpern, J. Chem. Soc., D 1971, 291; i) H. G. Kuivila, Adv. Organomet. Chem. 1964, 1, 47-87.

Submitted: October 26, 2018

Accepted: November 12, 2018 